\title{
Recent sightings of two very rare butterflies, Lethe margaritae Elwes, 1882 and Neptis nycteus de Nicéville, 1890, from Sikkim, eastern Himalaya, India
}

\author{
Sanjyog Rai ${ }^{1,5}$, Karma Dorjee Bhutia ${ }^{2,5}$ \& Krushnamegh Kunte ${ }^{3,4,5}$ \\ ${ }^{1}$ Mickkhola Busti, Namchi, South Sikkim, Sikkim 737126, India \\ ${ }^{2}$ C/o Rabzang Lama, Sikaritar Rumtek, P.O. Rumtek Dharma Chakra Centre, East Sikkim, Sikkim 737135, India \\ ${ }^{3}$ FAS Center for Systems Biology, Harvard University, 52 Oxford St., Northwest Lab Room 458.40-3, Cambridge, MA 02138, USA \\ ${ }^{4}$ National Center for Biological Sciences, GKVK, Bellary Road, Bengaluru, Karnataka 560065, India \\ ${ }^{5}$ Indian Foundation for Butterflies, No. 9, Sneha Nagar, Amruthahalli Main Road, Byatarayanapura, Bengaluru, India. \\ Email: ${ }^{1}$ sanjyogvet@gmail.com, ${ }^{2}$ kdgyatsov19@gmail.com, ${ }^{3}$ krushnamegh@ifoundbutterflies.org (corresponding author), \\ ${ }^{4}$ krushnamegh@ncbs.res.in
}

\begin{abstract}
Lethe margaritae Elwes, 1882 and Neptis nycteus de Nicéville, 1890 are very rare butterflies that are endemic to the Himalaya, and are legally protected in India. However, they have not been recorded in India in nearly 100 years. Here we review the available published information on their type localities, distribution and other natural history, and then report two recent sightings from Sikkim, northeastern India. Our sightings constitute rediscoveries of the Indian populations of these species.
\end{abstract}

Keywords: Endemism, faunal inventory, Lepidoptera Limenitidinae, Nymphalidae, Satyrinae, species rediscovery, type localities, Wildlife (Protection) Act, 1972.

Date of publication (online): 26 November 2012

Date of publication (print): 26 November 2012

ISSN 0974-7907 (online) | 0974-7893 (print)

Editor: George Mathew

Manuscript details:

Ms \# 02965

Received 10 October 2011

Final received 14 October 2012

Finally accepted 24 October 2012

Citation: Rai, S., K.D. Bhutia \& K. Kunte (2012). Recent sightings of two very rare butterflies, Lethe margaritae Elwes, 1882 and Neptis nycteus de Nicéville, 1890, from Sikkim, eastern Himalaya, India . Journal of Threatened Taxa 4(14): 3319-3326.

Copyright: @ Sanjyog Rai, Karma Dorjee Bhutia \& Krushnamegh Kunte 2012. Creative Commons Attribution 3.0 Unported License. JoTT allows unrestricted use of this article in any medium for non-profit purposes, reproduction and distribution by providing adequate credit to the authors and the source of publication.

Acknowledgements: We thank Vijay Barve and Gaurav Agavekar for coordinating our initial communication that resulted in this paper, and Ganesh Mani Pradhan and Chandan Jyoti Gogoi for supplying updated information about the historical localities mentioned in this paper. Motoki Saito provided details of the recent sighting of $L$. margaritae from Myanmar. We are grateful to S.T. Lachungpa (IFS, PCCF-cum-Secretary, Forests), N.T. Bhutia (IFS, PCCF-cum-CWLW) and Usha Lachungpa (Principal Research Officer, Wildlife) of the Department of Forest, Environment \& Wildlife Management, Government of Sikkim, for their continued support in documenting and monitoring butterfly diversity in Sikkim. The specimen depicted in Image 2 C-D is from the Museum of Comparative Zoology, Harvard University; thanks to Naomi Pierce for permission to photograph this specimen and to Rod Eastwood for his assistance in locating and photographing it. This work is part of an ongoing project to survey rare, endemic and legally protected butterflies in Sikkim Himalaya, which is partly funded by the Ashoka Trust for Research in Ecology and the Environment (ATREE) through an ATREE Small Grant For Research In Northeast India. This is Publication No. 4 of the Indian Foundation for Butterflies.

urn:Isid:zoobank.org:pub:23608402-76F9-477C-A6F0-C3E33027B253

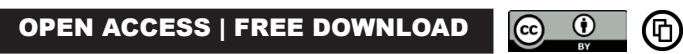

The eastern Himalaya host a significant proportion of India's butterfly diversity, where many species are endemic; some of them are very rare, and some are legally protected in India under the Indian Wildlife (Protection) Act, 1972 (Anonymous 1997; Gupta \& Mondal 2005). However, little natural history and ecological information exists on most of these species, and we know virtually nothing about their current status and distribution. Some of these species have either not been seen in India or not reported in the literature in decades. The lack of recent information on their habitats, exact elevational distributions and spot records, flight periods, early stages and larval host plants is hampering their conservation.

The renewed interest in the biology and conservation of Indian butterflies is slowly ameliorating this situation. Two species: Symbrenthia silana and Papilio elephenor, which had not been reported in nearly 100 years but protected under Schedule I of the Indian Wildlife (Protection) Act, 1972, were recently rediscovered from Sikkim and western Assam, respectively (Choudhury 2010; Kunte 2010). Current distributions of many other Schedule I and Schedule II species are being delineated and their populations assessed with recent sightings and quantitative data from various parts of the eastern Himalaya and northeastern India (Kunte et al. 2012).

In this paper, we report the sightings of two Schedule I species: Lethe margaritae and Neptis nycteus, from Chungthang and Rabum in the north Sikkim District of the state of Sikkim in northeastern India. We will first review published historical records and other information on their distributions, including their type localities because political boundaries have shifted around the type localities from the time 
of species descriptions. We will then provide exact locality details of our two sightings, which appear to represent the first published records of these species from India in nearly 100 years.

\section{Lethe margaritae Elwes, 1882 - Bhutan Treebrown}

Review of historical records, and distributional range of the species: Lethe margaritae Elwes, 1882 (Nymphalidae: Satyrinae: Satyrini), also known as the Bhutan Treebrown, was described from a single male (Elwes 1882). The female was subsequently described based on specimens supplied by de Nicéville and Elwes (Moore 1890-1892). The exact type locality of L. margaritae is unknown. Elwes (1882) provided the following details: "... I made arrangements with a native plant-collector, a Sikkim Bhotea, who had accompanied me on two expeditions into the interior, to visit the Chumbi Valley, on the Tibetan frontier of Sikkim, to collect seeds and insects. This he did during the months of August and September last. Though I cannot be certain of the exact localities in which they were taken, I have little doubt, from my knowledge of the country and the plants which came with them, that a considerable portion of them were taken on the Tibetan side of the frontier. On two occasions I have looked down into this valley from passes 15,000-16,000 feet high on the Chola range, which bounds Sikkim on the north-east; and, judging from what I saw and from the information we have obtained through native sources, it is a valley of somewhat different climate and vegetation from the Sikkim Valley, though the Machu River, which drains it, flows southwards through Bhotan to the Bay of Bengal. It is said to be much drier in summer and colder in winter than Sikkim valleys of similar elevation ...". Thus, although the title of Elwes's article was "On a collection of butterflies from Sikkim", the type locality of this species has subsequently been assumed to be somewhere in Bhutan (Moore 1890-1892; Bingham 1905; Talbot 1947).

This species has been reported or collected very rarely since the species was described. An unspecified number of specimens of both sexes was collected near Buxa, in Bhutan (Elwes \& Möller 1888; Moore 1890 1892). The species was subsequently reported from "Ta Shian Liang (5,000 ft), July 29" based on a single male (South 1913). This locality is believed to be in the Mishmi Hills (Talbot 1947; Gupta \& Mondal 2005) in central to eastern Arunachal Pradesh, but we have been unable to confirm whether this is the case and find out anything about it. It could prove to be in southeastern Tibet on the border with Arunachal Pradesh. A female specimen, currently in the Natural History Museum (London), was collected from "Darjeeling-Tukvar" (d'Abrera 1985), although we do not know the date of collection of this specimen. Tukvar is near Darjeeling Town, Darjeeling District, West Bengal, at an elevation of ca 1,200-1,500m. Finally, the latest record of the species was a male collected on 22 July 2000 near the Tonwang-Dabudam Village in the Kachin State of Myanmar, in dense evergreen forest (Shizuya et al. 2005).

As far as we know, the above few reports comprise the entire original historical record for this species. Several major books merely list the species from Bhutan, without any new information about the species or details of any new specimens (Marshall \& de Nicéville 1882; Bingham 1905; Antram 1924; Talbot 1947; Wynter-Blyth 1957). Therefore, we assume that these records were largely taken from published literature. The National Zoological Collection of the Zoological Survey of India (ZSI) in Kolkata has three specimens of unspecified sex from Bhutan (Gupta \& Mondal 2005), although these specimens were part of the pre-independence British collection that ZSI inherited. We do not know in what condition the ZSI specimens are because Gupta and Mondal copied photographs from d'Abrera (d'Abrera 1985) instead of using pictures of the ZSI specimens. The Museum of Comparative Zoology at Harvard University does not have any specimens. The species has not been reported from Nepal (Smith 1989, 2006).

Based on available evidence, the species is known to occur only in four specific localities: Buxa in Bhutan, Tukvar in Darjeeling District of West Bengal, Ta Shian Liang, which is presumably in the Mishmi Hills of Arunachal Pradesh, and Tonwang-Dabudam area in Kachin, Myanmar. Of these, the West Bengal record had not been recognized as such, so this review adds the state of West Bengal to the known range of this species. We also note that the Kachin record has extended the range of the species eastward by approximately $200 \mathrm{~km}$ to Myanmar, and that was a rediscovery of the species. Despite the mention of this species from Sikkim (see 
below), there are no historical records from the state of Sikkim as currently politically recognized. Within a few years of describing this species, Elwes included it in his checklist of Sikkim butterflies but wrote: "I am as yet uncertain whether this beautiful species occurs in Sikkim or not, as my first specimen was brought by native collectors from some place to the eastward of the Tista River; but Mr. Knyvett's collectors have lately taken others of both sexes near Buxa, in Bhotan, and I have no doubt it occurs near to, if not within, British Bhotan ..." (Elwes \& Möller 1888). In his subsequent checklist of butterflies, de Nicéville also listed the species for Sikkim but noted, "A rare species obtained by the native collectors only near Buxa, Bhutan" (de Nicéville 1894). Later, the distribution was mentioned as "SIKKIM to BHUTAN, and in the MISHMI HILLS" (Talbot 1947), "Bhutan, Sikkim" (d'Abrera 1985), and "India: Sikkim; Arunachal Pradesh (Mishmi Hills). Elsewhere: Bhutan.” (Gupta \& Mondal 2005). The species was recently listed for Sikkim, but without any details (Haribal 1992). Evidently, all the subsequent Sikkim mentions were taken from the Elwes-de Nicéville butterfly checklists for Sikkim, in which they had clearly stated that the species did not occur in Sikkim but listed it there, anyway. We must conclude that the species had never actually been collected from Sikkim.

\section{Elevational range and flight period}

The only specific elevation from which this species has so far been reported is "5,000 ft" (South 1913). The elevational range given by Talbot, "from about 5,000 to $16,000 \mathrm{ft}$ " (Talbot 1947), is apparently based on a misunderstanding of Elwes's description. As mentioned above, the only prior mention of " 16,000 feet" was by Elwes when he described what he had seen from the mountain pass into the lower valley from which the male type specimen may have been collected, "On two occasions I have looked down into this valley from passes 15,000-16,000 feet high on the Chola range" (Elwes 1882). Thus, based on the single record of South, the species is expected to occur at mid-elevations around $1,500 \mathrm{~m}$. The known flight period is from the end of July (South 1913; Shizuya et al. 2005) to August or September when the type specimen was collected (Elwes 1882).

\section{Status}

This species is apparently the largest member of the genus Lethe, with a wingspan of 85-95mm (de Nicéville 1894; Talbot 1947; d'Abrera 1985). It has been reported to be very rare, especially the female (Antram 1924; Evans 1932; Talbot 1947; Wynter-Blyth 1957). The species is legally protected in India under Schedule I of the Indian Wildlife (Protection) Act, 1972 (Anonymous 1997), and listed as endangered according to Gupta \& Mondal (2005). Its early stages and larval host plants are unknown.

\section{Our new record}

SR sighted L. margaritae at Chungthang (approx. $27^{0} 36^{\prime} \mathrm{N} \& 88^{\circ} 38^{\prime} \mathrm{E}$ ), a small town in the North Sikkim District. Chungthang, at an altitude of $1,700 \mathrm{~m}$, is at the confluence of Lachen and Lachung rivers, which are then recognized as Teesta River downstream of the confluence. The area was originally covered with midelevation mixed forests, but now forests are restricted to very small fragments mostly on steep slopes. A large dam is currently being constructed as part of a hydroelectric project near Chungthang, which will further decimate forests in this area.

Lethe margaritae was sighted in the town on the cool, rainy late evening (19:25 hr) of 26 July 2011. It was resting on a leaf of an ornamental Geranium plant outside a house. On being disturbed, it flew through an open window into one of the rooms inside the house. There it perched right next to an electric lamp that had previously been turned on, its proboscis slowly curling and uncurling, and wings partly spread. After taking a few pictures, SR released the butterfly outside the house, and it was not seen again.

SR's photographs (Image 1) agreed very well with the previously published illustrations and photographs of male L. margaritae (Elwes 1882; Moore 18901892; d'Abrera 1985). The specimen exactly matched the identification key and other descriptions of Indian Lethe, mainly: (a) it was exceptionally large for a Lethe, (b) it had a narrow yellow discal band on upper forewing, and (c) on the under hindwing, it had a very prominent pale band passing through the end of cell but had no discal band (Evans 1932; Talbot 1947). The elevation $(1,700 \mathrm{~m})$ at which SR sighted this specimen and the date (26 July) on which it was seen are similar to the previously known elevational range $(1,500 \mathrm{~m})$ and the flight period (end of July to August or September) 

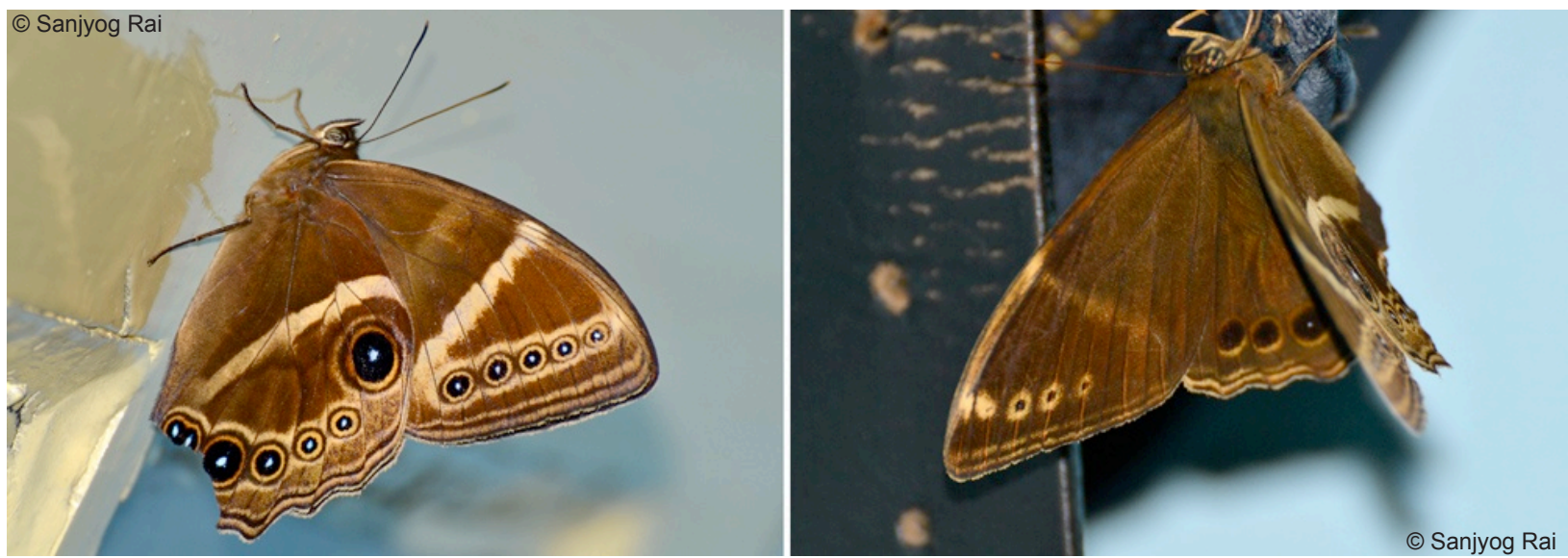

Image 1. Male Lethe margaritae at Chungthang, North Sikkim District, Sikkim, India; 1,700m elevation; 26.vii.2011.

of the species (Elwes 1882; South 1913).

\section{Neptis nycteus nycteus de Nicéville, 1890 - Hockeystick Sailer}

Review of historical records, and distributional range of the species: Neptis nycteus de Nicéville, 1890 (Nymphalidae: Limenitidinae: Neptini), or the Hockeystick Sailer, was described from three specimens: "The type male specimen in Mr. G.C. Dudgeon's collection was taken in June; the type female in my own collection was taken in July; and a second female specimen in Mr. A.V. Knyvett's collectionwere all taken at Tongloo on the Singalelah range at an elevation of about 12,000 feet" (de Nicéville 1890). de Nicéville mentioned the "HABITAT" of his new species as "Sikkim", so the type locality (or 'habitat') has subsequently been given as Sikkim (Moore 1899-1900; Eliot 1969). This needs a comment and a change. It is clear from de Nicéville's description that the type specimens were collected from Tonglu (=Tongloo; approx. $27^{\circ} 02^{\prime} \mathrm{N} \& 88^{\circ} 04^{\prime} \mathrm{E}$ according to Google Earth), which is one of the highest points on the Singalila Range (or Ridge). Tonglu is at an elevation of $3,046 \mathrm{~m}$, which is $9,993 \mathrm{ft}$ and not $12,000 \mathrm{ft}$ as mentioned in the original species description. Tonglu and the Singalila Range are in the Darjeeling District, which was loosely included in "Sikkim" at the time of the species description, but it now belongs to the state of West Bengal. Since political boundaries have shifted in this area and appear quite stable at present, the type locality of $N$. nycteus should now be given as: Tonglu, Singalila Range, Darjeeling District, West Bengal. It is flanked by Sikkim (as currently politically recognized) to the north and Nepal to the west.

Very few records of this species have been published before or since the species description. Elwes "took a single fresh male, ... in the forest near the Rangbi jhora, on the road to Serail, at $6000 \mathrm{ft}$., on June 7th" (Elwes \& Möller 1888). Rangbi has a small forest river, and it is also close to Senchal. Serail is a small settlement situated $8 \mathrm{~km}$ west of Mungpoo, which is $35 \mathrm{~km}$ southeast of Darjeeling in West Bengal. However, N. nycteus had not been described at the time of his paper, so Elwes had assigned his specimen to Neptis manasa Moore, 1857. de Nicéville wrote of Elwes's record under Neptis nycteus in his own checklist of Sikkim butterflies: "This is No. 131, Neptis manasa, Moore, of Mr. Elwes' list", further mentioning that the species was "Found by Mr. Dudgeon at 7,000 feet in Daling." (de Nicéville 1894). Dudgeon's specimen (sex unknown) from Daling should be different from the male type from Tonglu used by de Nicéville (1890). Daling, also variously known as Dalingkote or Dalimkote, was a historic fort that is now under the Kalimpong subdivision of the Darjeeling District, West Bengal. There was a male in Swinhoe's collection, "taken by a native collector at "Lachin Lachoong, 8000 to 16,000 feet elevation"" (Moore 1899-1900). Lachen and Lachung are in the North Sikkim District of modern Sikkim (see below). Bingham did not report any new specimens (Bingham 1905). Eliot mentioned distribution of this species from Bhutan (Eliot 1969), so the Natural History Museum (London) appears to have specimen(s) taken 
from that country, although we do not know the details of these specimens. Since 1969, the species has been reported as "Very Rare" from Manang and Kathmandu in central Nepal, which has extended the species range northwestward by approximately $300 \mathrm{~km}$ (Smith 1989). There are three specimens in the collection of the ZSI Kolkata (Gupta \& Mondal 2005), although we suspect that these were among the specimens listed by de Nicéville in previous literature (de Nicéville 1890, 1894) (de Nicéville was curator at the Indian Museum, where many of his specimens were and still are deposited, and which is now part of the ZSI Kolkata). As far as we know, this is the complete compilation of all the published records for this species.

The species range has so far been variously given as only in Sikkim (Moore 1899-1900; Evans 1932), or Sikkim and Bhutan (Eliot 1969; d'Abrera 1985), or central Nepal to Sikkim and Bhutan (Smith 1989, 2006). From the above discussion regarding the type locality, northern West Bengal should now be included in the range of the species, from where most Indian examples appear to have been taken. On the other hand, only one historical record, that of the male from Lachen/Lachung in Swinhoe's collection(Moore 18991900), can be attributed to the modern state of Sikkim. The species was mentioned for Sikkim but without any information in two important books (WynterBlyth 1957; Haribal 1992), so we assume that this was based on historical records summarized above and not on any new records. A subspecies, Neptis nycteus menpae Huang, 1998, has recently been described from Hamni, Metok, southeastern Tibet (Huang 1998), which is approximately $700 \mathrm{~km}$ northeast of the range of the nominotypical subspecies. Evans (1932) mentioned another subspecies, phesimensis Tytler, 1915, from the Naga Hills, but this taxon is now treated as a subspecies under Neptis nemorum Oberthür, 1906 based on the similarities of the male genitalia with that species (Eliot 1969).

\section{Elevational range and flight period}

The elevational range of this species is given as 1,767m to 4,875m (Moore 1899-1900; Smith 1989; Gupta \& Mondal 2005). The higher end of this range $(4,875 \mathrm{~m})$ is based on the male taken at Lachen/ Lachung at "8000 to 16,000 feet elevation" (Moore 1899-1900). The Lachen and Lachung areas in the North Sikkim District indeed cover this elevation range, but here the tree line is well below $4,800 \mathrm{~m}$, so the " 16,000 feet" elevation must be wrong. We must conclude that this specimen was collected at a lower elevation in the range of 2,400-3,500 m near Lachen or Lachung, where a suitable habitat for this Neptis exists. The elevational range of this species can therefore be determined to be approximately 1,800 to $3,500 \mathrm{~m}$. Thus, this is a mid- to high-elevation species, and it appears to have a single brood per year. The flight period has been reported to be June-July in the Singalila Range (de Nicéville 1890), and May-June in Manang and Kathmandu in central Nepal (Smith 1989).

\section{Status}

The species has been reported as very rare (Evans 1932; Wynter-Blyth 1957; Smith 1989). It is legally protected in India under Schedule I of the Wildlife (Protection) Act, 1972 (Anonymous 1997), and listed as critically endangered by Gupta \& Mondal (2005). Its early stages and larval host plants are unknown.

\section{Our new records}

KDB sighted $N$. nycteus nycteus twice at Rabum (approx. $27^{\circ} 44^{\prime} \mathrm{N} \& 88^{\circ} 32^{\prime} \mathrm{E}$ ), a small village about $18 \mathrm{~km}$. from the town of Lachen in the North Sikkim District. This was at an altitude of $2,990 \mathrm{~m}$, and on the road leading to the Gurudongmar Lake. The region is mountainous and rugged, with some high-elevation stunted forests, small human settlements and sparsely dispersed agricultural and pastoral fields.

The first sighting was made on 21 June 2011 at 09:23hr, when the butterfly was feeding from fresh cow dung on the road while slowly opening and closing its wings. The second sighting, which may or may not be of the same individual, was made two days later, on 23 June 2011 at 11:54hr, around the same location (Image $2 \mathrm{~A}-\mathrm{B})$. This time the butterfly was perched on a small Urtica shrub. It had rained the previous night, and the weather was gloomy when KDB spotted the butterfly. The butterfly basked in the occasional mild sunshine with its wings spread flat. It tolerated human presence, but it would fly off and settle on a nearby weed when approached too closely. The sex of the specimen(s) that KDB photographed is unknown.

We would also like to take this opportunity to report another spot record from Gangtok, the state capital of Sikkim. This is based on the sole specimen of this 

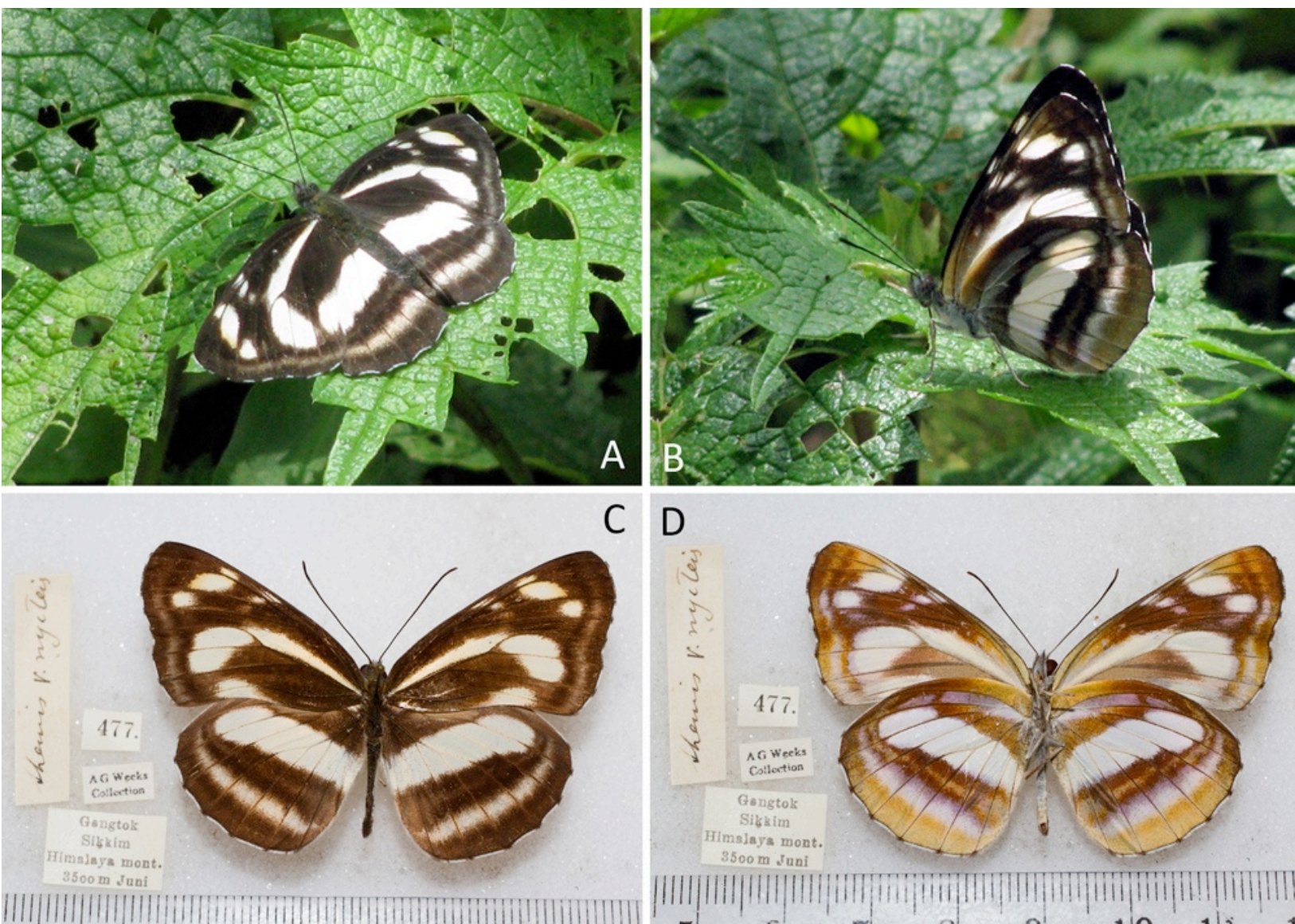

C D

Image 2. Neptis nycteus nycteus in Sikkim, India. A-B - At Rabum, near Lachen, on the road to Gurudongmar Lake, North Sikkim District; 2,990m elevation; 23.vi.2011. C-D - Gangtok, East Sikkim District; 3,500m elevation; date unknown, presumably late 1800 s or early 1900 s; currently deposited in the butterfly collection at the Museum of Comparative Zoology, Harvard University, USA. Photographs and copyright: A-B: Karma Dorjee Bhutia. C-D: photographs: Krushnamegh Kunte, copyright: President and Fellows of Harvard College.

species in the butterfly collection at the Museum of Comparative Zoology, Harvard University, USA (Image 2C-D). The four labels currently attached to this specimen read: (1) "Gangtok Sikkim Himalaya mont. 3500 m Juni”, (2) "A G Weeks Collection”, (3) "477" and (4) "Shemis v. nycteis". The collection date of this specimen is unknown, but assumed to be from the late 1800 s to very early 1900 s, when most of the specimens from the A.G. Weeks collection were presumably acquired (Rod Eastwood, personal communication).

The photographed individuals (Image 2) agree well with the previously published illustrations and photographs of several specimens of this species (Moore 1899-1900; d'Abrera 1985; Smith 1989; Gupta \& Mondal 2005; Smith 2006). They also closely follow the identification keys and other descriptions of Indian Neptis, mainly: (a) the upper forewing discal spot in three joins cell streak, forming a hockey sticklike curved marking, (b) this spot does not fill the base of 3, (c) all the markings are white, (d) the underside is rich ochre brown, and (e) under hindwing basal area, especially the cell, has white markings (Evans 1932; Eliot 1969).

\section{Conclusions}

Our sighting of Lethe margaritae appears to be the first one reported since 1913 in India, therefore it constitutes a rediscovery of the species in the country. As far as we know, it is only the second record of the species in the past 100 years throughout its range, following the recent sighting in Kachin, Myanmar, in July 2000. It also confirms the distribution of the species in Sikkim. Neptis nycteus has recently been recorded from central Nepal (Smith 1989, 2006) and it occurs in Bhutan (Eliot 1969), but our sightings 


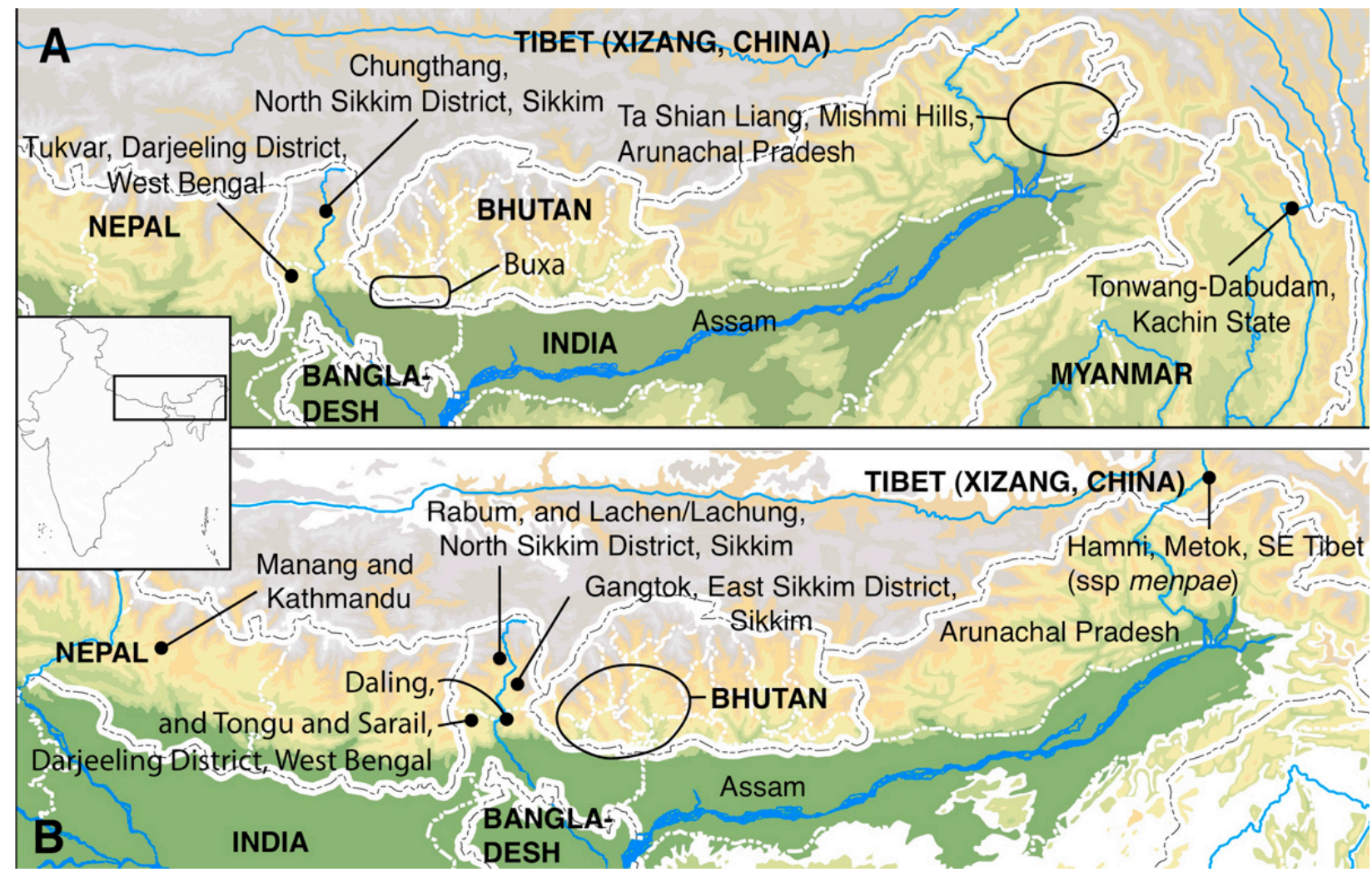

Image 3. Distributional maps of Lethe margaritae (A) and Neptis nycteus (B). () Krushnamegh Kunte

appear to be the first ones to be reported from India in several decades. These spot records indicate localities, elevations and habitat types where more intensive surveying and monitoring efforts are needed with the hope of accumulating further sightings of these very rare and endemic butterflies (Image 3 ).

All the available information on the occurrence of these two species, reviewed above, along with our new records, may be briefly summarized as follows:

1. Lethe margaritae: This species was described from a male specimen collected most likely somewhere in Bhutan. Only five specific localities are now known for this species: Tukvar (Darjeeling District, West Bengal), Chungthang (North Sikkim District, Sikkim), Buxa (Bhutan), Ta Shian Liang (presumably in the Mishmi Hills, Arunachal Pradesh), and Tonwang-Dabudam (Kachin State, Myanmar). The species is thus narrowly endemic to the approx. $1,000 \mathrm{~km}$-long strip of mid-elevation evergreen forest in the eastern Himalaya, from Darjeeling to Kachin. It occurs at 1,500-1,700 $\mathrm{m}$ from the end of July up to September, and appears to be univoltine. It is one of the rarest eastern Himalayan butterflies, and it is legally protected in India under Schedule I of the Wildlife (Protection) Act, 1972.

2. Neptis nycteus: This species was described from Tongu in the Singalila Range, Darjeeling District, West Bengal. The nominotypical subspecies has subsequently been reported from Manang and Kathmandu (Kathmandu District, central Nepal), Rangbi jhora near Sarail and Daling (Darjeeling District, West Bengal), Gangtok (East Sikkim District), Rabung and Lachen/Lachung (North Sikkim District), and Bhutan. The nominotypical subspecies thus occurs from central Nepal to Bhutan. Subspecies Neptis nycteus menpae Huang, 1998 has so far been reported only from Hamni, Metok, SE Tibet. The species on the whole is thus endemic to a strip of approx. $1,000 \mathrm{~km}$ in the central and eastern Himalaya. The elevational range of the species is $1,800-3,500 \mathrm{~m}$. It is univoltine, and flies from May to July. It is a very rare species that is legally protected in India under Schedule I of the Wildlife (Protection) Act, 1972.

Additional pictures of these two species are available online at:

http://ifoundbutterflies.org/441-lethe/lethe-margaritae 
http://ifoundbutterflies.org/153-neptis/neptis-nycteus

Additional information and pictures will be made available on the above pages as they accumulate with further sightings in Sikkim and elsewhere in India.

\section{REFERENCES}

Anonymous (1997). The Wildlife (Protection) Act, 1972 (as amended up to 1993). 4th updated edn. Natraj Publishers, Dehra Dun, 158pp.

Antram, C.B. (1924). Butterflies of India. Thacker, Spink \& Co., Calcutta (Kolkata), 226pp.

Bingham, C.T. (1905). The Fauna of British India, including Ceylon and Burma (Butterflies), Vol. 1. Taylor and Francis, London, 537pp.

Choudhury, K. (2010). Rediscovery of two rare butterflies Papilio elephenor Doubleday, 1845 and Shijimia moorei Leech, 1889 from proposed Ripu-Chirang Wildlife Sanctuary, Assam, India. Journal of Threatened Taxa 2(4): 831-834.

d'Abrera, B. (1985). Butterflies of the Oriental Region. Part II: Nymphalidae, Satyridae \& Amathusidae. Hill House, Melbourne, 246-534.

de Nicéville, L. (1890). On new and little-known butterflies from the Indian Region, with descriptions of three new genera of Hesperiidae. Journal of the Bombay Natural History Society 5: 199-225.

de Nicéville, L. (1894). A list of the butterflies of Sikhim, pp. 116-187. The Gazetteer of Sikhim. Bengal Secretariat Press, Calcutta (Kolkata).

Eliot, J.N. (1969). An analysis of the Eurasian and Australian Neptini (Lepidoptera: Nymphalidae). Bulletin of the British Museum, Natural History (Entomology) Suppl. 15: 3-155+153 B\&W plates.

Elwes, H.J. (1882). On a collection of butterflies from Sikkim. Proceedings of the Zoological Society, London 1882: 398 407.

Elwes, H.J. \& O. Möller (1888). A catalogue of the Lepidoptera of Sikkim; with additions, corrections, and notes on seasonal and local distribution. Transactions of the Entomological Society, London 1888: 269-464.

Evans, W.H. (1932). The Identification of Indian Butterflies. 2nd edition. Bombay Natural History Society, Mumbai, $454 \mathrm{pp}$.

Gupta, I.J. \& D.K. Mondal. (2005). Red Data Book (Part-2)
- Butterflies of India. Zoological Survey of India, Kolkata, $535 \mathrm{pp}$.

Haribal, M. (1992). The Butterflies of Sikkim Himalaya and their Natural History. Sikkim Nature Conservation Foundation, Gangtok, 217pp.

Huang, H. (1998). Research on the butterflies of the Namjagbarwa Region, S.E. Tibet. Neue Entomologische Nachrichten 41: 207-263.

Kunte, K. (2010). Rediscovery of the federally protected Scarce Jester Butterfly Symbrenthia silana de Nicéville, 1885 (Nymphalidae: Nymphalinae) from the Eastern Himalaya and Garo Hills, northeastern India. Journal of Threatened Taxa 2(5): 858-866.

Kunte, K., S. Sondhi, B.M. Sangma, R. Lovalekar, K. Tokekar \& G. Agavekar (2012). Butterflies of the Garo Hills of Meghalaya, northeastern India: their diversity and conservation. Journal of Threatened Taxa 4(10): 29332992.

Marshall, G.F.L. \& L. de Nicéville. (1882). The Butterflies of India, Burmah and Ceylon. Volume I. Nymphalidae. Danainae, Satyrinae, Elymniinae, Morphinae, Acraeinae. The Calcutta Central Press Co., Calcutta (Kolkata), 327pp.

Moore, F.(1890-1892). Lepidoptera Indica. Vol. I. Rhopalocera. Family Nymphalidae. Sub-families Euploeinae and Satyrinae. Reeve \& Co, London, 317, Plates 311-394pp.

Moore, F. (1899-1900). Lepidoptera Indica. Vol. IV. Rhopalocera. Family Nymphalidae. Sub-families Nymphalinae (continued), groups Limenitina, Nymphalina, and Argynnina. Reeve \& Co, London, 260, Plates 287378pp.

Shizuya, H., Y. Watanabe, M. Saito \& T. Soe. (2005). Basic information on butterflies of Kachin State, Myanmar (Part 2). Butterflies 39: 29-39.

Smith, C. (1989). Butterflies of Nepal (Central Himalaya). Tecpress Service L.P., Bangkok, 352pp.

Smith, C. (2006). Illustrated Checklist of Nepal's Butterflies. $2^{\text {nd }}$ Revised Edition. Walden Book House, Kathmandu, $129 \mathrm{pp}$.

South, R. (1913). A list of butterflies collected by Captain F. M. Bailey in western China, south-eastern Tibet, and the Mishmi Hills, 1911. Journal of the Bombay Natural History Society 22: 345-365, 598-615.

Talbot, G. (1947). The Fauna of British India, including Ceylon and Burma: Butterflies, Vol. 2. Taylor and Francis, London, 506pp.

Wynter-Blyth, M.A. (1957). Butterflies of the Indian Region. Bombay Natural History Society, Mumbai, 523+572 plates. 